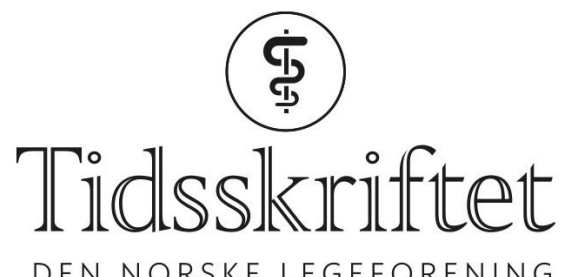

\title{
Antistoff mot follikelstimulerende hormon som fedmebehandling?
}

FRA ANDRE TIDSSKRIFTER

HAAKON B. BENESTAD

Universitetet i Oslo

Antistoff mot follikkelstimulerende hormon ga mindre fedme, $ø$ kt benmasse og endret fettvev hos overvektige individer i en musestudie.

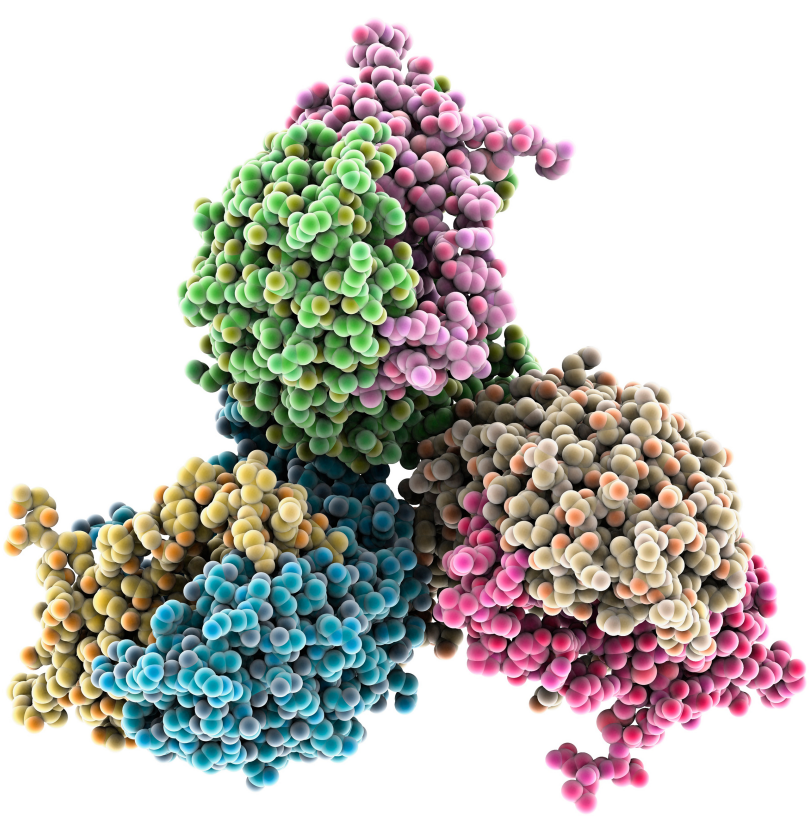

Modell av follikkelstimulerende hormon-kompleks med reseptor. lllustrasjon: Science Photo Library

Reseptorer for follikkelstimulerende hormon (FSH) finnes i mange vev og organer, bl.a. benvev. Mange kvinner har i en 2-3-årsperiode før menopausen stigende FSHkonsentrasjoner i blodet og et noenlunde bevart østrogennivå. Dette er perioden da vektøkning, bukfedme og bentap setter inn og den fysiske aktiviteten ofte blir mindre. I en ny studie med en musemodell ble en hypotese om at $ø$ kte FSH-effekter kan forklare disse endringene testet (1).

Et polyklonalt antistoff mot betasubenheten i hormonet ble injisert i bukhulen på overvektige mus ukentlig i åtte uker. Denne FSH-blokkeringen førte til økt benmasse, redusert mengde fettvev, økt fettfri vekt og endringer i fettvevet - det lignet såkalt beige fett, 
der en større del av forbrenningen gir varme og mindre ATP-danning enn i hvitt fettvev. Forandringene skyldtes ikke økt aktivitet eller $ø$ kte nivåer av noradrenalin, irisin, adipokininer eller østradiol. Et monoklonalt antistoff mot den humane FSH $\beta$-epitopen reproduserte de gunstige effektene, og fedmereduksjon ble også påvist i mus uten ovarier.

- Dette er svært interessante og spennende resultater fra et forskningsfelt som er i rask utvikling, sier Jøran Hjelmesæth, som er professor ved Universitetet i Oslo og Senter for sykelig overvekt, Sykehuset i Vestfold.

- Godt over halvparten av vårt daglige kaloriinntak forbrennes i hvile, og mange som sliter med fedme, kan tenkes å ha god nytte av medikamenter som øker hvileforbrenningen ytterligere, sier han.

- Men det er en lang og kronglete vei fra spennende musefors $\emptyset \mathrm{k}$ til ny behandlingspraksis. Altfor ofte er vi blitt skuffet av kliniske studier basert på lovende dyrestudier der det har vært små effekter hos mennesker eller en uakseptabel bivirkningsprofil, sier Hjelmesæth.

LITTERATUR:

1. Liu P, Ji Y, Yuen T et al. Blocking FSH induces thermogenic adipose tissue and reduces body fat. Nature 2017; 546:107-12. [PubMed][CrossRef]

Publisert:30. oktober 2017. Tidsskr Nor Legeforen. DOI: 10.4045/tidsskr.17.0751

(C) Tidsskrift for Den norske legeforening 2020. Lastet ned fra tidsskriftet.no 